\title{
間接評価を用いた空間の演出効果の推定
}

\author{
横井＼cjkstart聖宏，中島＼cjkstart瑞季，山中＼cjkstart敏正
}

筑波大学大学院

\section{Estimating the Affection of the Exhibition Space by an Indirect Method}

\author{
Takahiro YOKOI, Mizuki NAKAJIMA and Toshimasa YAMANAKA
}

University of Tsukuba, Graduate School of Comprehensive Human Science, 1-1-1 Tennodai, Tsukuba-shi, Ibaraki 305-8577, Japan

\begin{abstract}
This is an examination of the effect of elements of the space to people's action. The combination of the wallpaper and the color temperature of lighting of the space changes the impression of the space. But, it is not obvious whether the effect works on people's action or not. So, we investigated people's action, evaluating a chocolate in an exhibition space and estimated the effect of combination of the wallpaper and the lighting by the evaluation of a chocolate. In the experiment, participants were told to evaluate chocolates, and we compared the result by the difference of the wallpaper and the color temperature of lighting of the space. The reason to use such a method is that people can't speak about the real intention of their actions. By the experiment, we discovered that however participants were not aware, the difference of the wallpaper and the lighting of the space affected the intention to purchase the chocolate in some case.
\end{abstract}

Keywords : Evaluation of Space, Indirect Method, Affection

\section{1. は じめに}

これまで, 空間の視覚環境を構成する要素が人に与える印 象に関する研究は照明の効果を中心に数多く行われている. そのような研究について租 [1] は, 空間を構成する要素単 体の効果を, 他の要素を統制して個別に求めただけでは研究 結果が現実の建築環境でも即, 有用であるとは言えないと指 摘し, 照明パターン, 壁面色彩, 壁面素材の複数要素を設定 した空間の印象評価実験を行った。そのの結果，要素間にいく つかの交互作用が見られ, 空間を構成する要素を複合的に評 価することの必要性が示唆された，また，中村［2］は空間 の照度・色温度の雾囲気を「だんらん」,「くつろぎ」といっ た実際の行為の場と想定した場合の好ましさについて評価さ せ，想定する行為によって評価が変化することを確認した。 これらの研究に関連するものとして, 魯 [3]は「くつろぐ」, 「だんらん」,「読書をする」,「テレビ・ビデオを見る」,「飲 食をする」，「音楽を聴く」の6つの生活空間におけるリラッ クス行為について, 空間の照明条件と内装の色彩の組み合わ せの好ましさを評価させたところ, 特徴的なものとして, 視 覚を主としない行為である「音楽を聴く」については, 特に 壁と床が白の場合に照明の色温度が高くなるにつれ顕著に好 ましさが低下し, 逆に視覚を中心とした行為の「読書をする」 では内装の色に関わらず照明の色温度が最も低い3000Kの 場合に特に好ましさが低くなるといった結果を示した。こう いった方法で, 要素の組み合わせの効果や, 空間の使用目的 を考慮して評価を取得することは, 意図した印象を与える空 間を構築するための指標を得るには有効である.

ただし, 中村や魯の研究のように空間を呈示しながらそこ
で行為をしている場面を想像させて評価を得る方法は, 行為 が人の想像の中で完結しており，ある行為に好ましいという 印象を与えた空間が実際にその行為に適した効果を持つ空間 だと簡単に結論付けることはできない，

一方, 勝浦 [4] は光の色温度の影響は確実に自律神経反 応に現れ, 高色温度光は身体機能を刺激し緊張をもたらす効 果があると述べており, 永留 [5］は壁面が青色の空間は壁 面が赤色の空間よりも空間内で人の感覚時間が長くなること を確認した。これは, 空間の構成要素の違いが, 空間内での 人の行為の結果を変化させる可能性を示すものである。た が, 人の行為の多くは意識がアクセスできない潜在過程の直 接の結果である [6] と言われており，自身でさえ認識する ことができない，そのため，拈そらく大半の人は，空間の壁 面の色や照明の色温度が違うことで自身の行為の結果が変わ るとは考えないだろう。下條 [7] は，人が説明する意図の 多くは周囲の状況や結果から判断し, もっともらしく作り上 げた後付けのものであるとしている。したがって，意識に上 らないような空間の効果を，直接的な質問で人に的確に説明 させることは難しい.

このような背景を受けて, 本研究では構成要素の異なる空 間では人の行為の結果にも差が見られるかを, 直接的な回答 を得て評価するのではなく, 空間内での人の行為の結果から 推定する間接的な方法で検討を行った.

\section{2. 実 験}

\section{1 目 的}

実験から明らかにしたいことは, 同一の行為であっても空 間の視覚環境が異なることでその結果に差異が生じるのかと 
いうことである，そこで，空間の構成要素を操作することで 複数の条件の空間を用意し, 各空間で実験参加者に同一の夕 スクを求めて結果を比較することで空間の効果を推定する.

\section{2 タスク}

実験参加者に求める夕スクは結果を定量的に観察でき，か つ，本研究の目的から視覚的な処理を含む行為が望ましいた め，得られる結果が明確で比較が容易な 5 段階評価法を用い て，実験空間内で呈示した商品を見ながら評価を行うタスク を設定した，評価対象となる商品には，評価が直感的に行わ れやすいと考えられる嗜好品の中から，視覚的特徵のバリ エーションが豊富で，なじみが梁く評価しやすいという理由 でチョコレートを採用した。

空間の違いによってチョコレートの評価に差が生じたかを 検討するには，各実験参加者に対して複数の空間で評価をさ せ，空間ごとのチョコレートの評価值を実験参加者間で比較 する方法が適当である。よって, 1 つの空間で 1 種類のチョコ レートを評価させ，空間の条件数と同数の種類のチョコレー トを用意し，すべての空間でこれを繰り返すことにした，

また，チョコレート評価タスクの結果と空間の構成要素の 印象との関連を調べるため, 各空間についての印象評価を取 得する空間評価タスクを別に設けた。

\section{3 環 境}

外部光を遮断した実験室内に，図1のようなチョコレート 呈示用のテーブルとテーブルを囲む3面の壁紙貼り付け用パ ネルを図2のように設置し, その背後の実験とは無関係な空 間が見えないよう壁紙貼り付けパネルの左右や上部, テーブ ルの前面には目隠しを施した。左右の壁紙貼り付けパネルの 上端手前側の角と, 左右のパネル上部に渡したレールの中間 の計3箇所にはクリップライトを取り付けた。壁紙は正面, 左面, 右面のパネル 3 面に同種のものをマジックテープで貼 り付けた状態で呈示し, 照明は3台のクリップライトに同種 の電球を取り付け，それぞれから最も距離の遠いパネルに貼 られた壁紙を照らすよう点灯した。テーブル上の照度は色彩 照度計（コニカミノルタセンシング製CL-200）を用いて測 定し，壁紙，照明がいずれの組み合わせでもJIS Z 9110 照 度基準において定められた教室等での机上視作業に適する照 度基準（維持照度3001x）を満たしていることを確認した。

\section{4 実験空間の構成要素および刺激}

\subsection{1 壁紙}

実験空間の壁紙はリリカラ製LB-9238石目調 [図3 左：W1， サンゲッ製FE-4216和調 [図3中:W2]，東リ製WVP3172塩 化ビニル樹脂系壁紙［図3右：W3］の3種類を用いた。

これらは, 先に行った視覚的特徵による壁紙の分類に関 する研究 [8] で得られた壁紙の視覚的特徵を表すカテゴリ のうち, 特に明確な特徴を表した「シンプル」,「和風」,「洋 風」の各カテゴリに該当するものを 1 種類ずつ選出した物で ある。

\subsection{2 照明}

照明には電球色（2800K，59cd，Ra84）[図4左：L1], 昼白色 (5000K, 57cd, Ra84) [図 4 中: L2], 昼光色 (6700K, $53 \mathrm{~cd}, \mathrm{Ra} 84$ ) [図4 右：L3] の3 種類の電球型蛍光灯（東芝

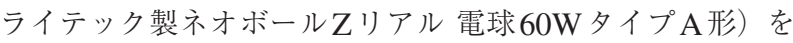
用意し，ヤザワ製クリップライトCLED10012WHに取り付 け点灯させた。

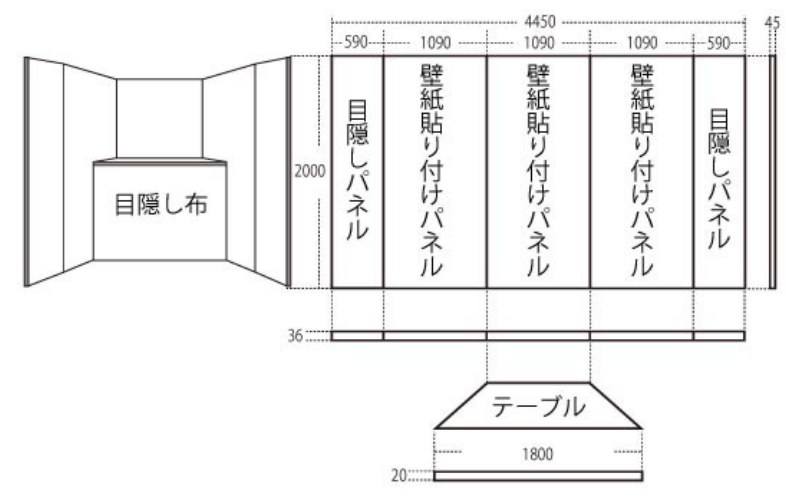

図1 パネルおよびテーブルの設計図

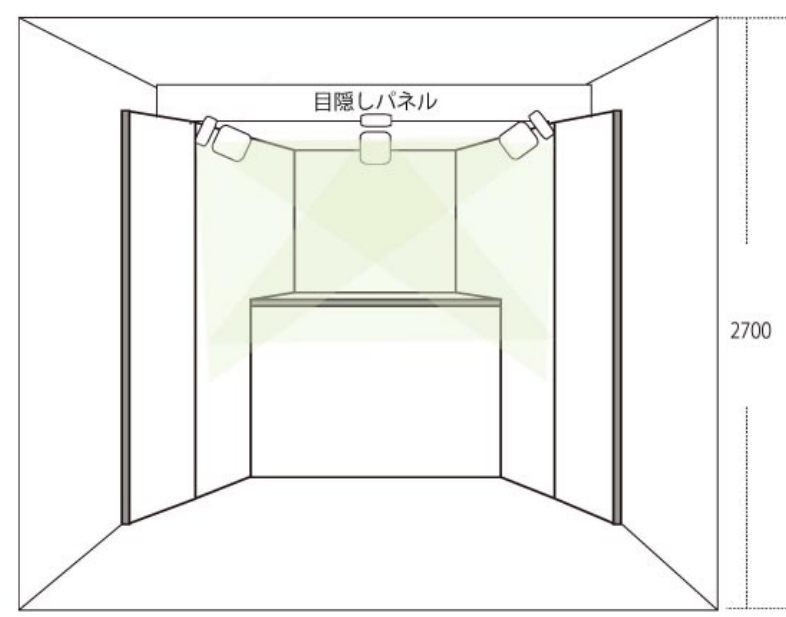

図2 実験空間の設計図

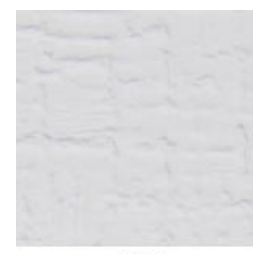

W1

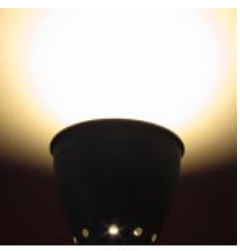

L1

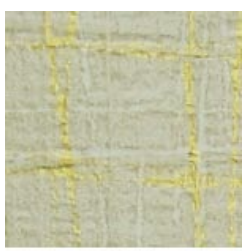

W2

図3 壁紙

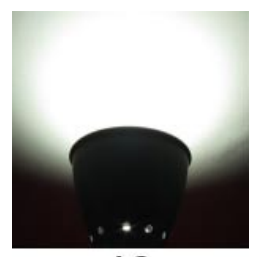

$\mathrm{L} 2$

図4 照明

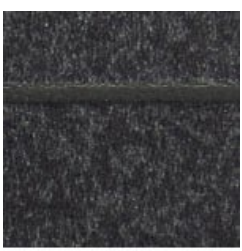

W3

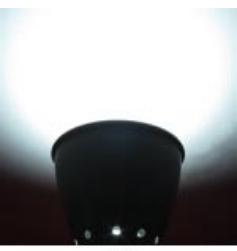

$\mathrm{L} 3$ 


\subsection{3 実験空間}

実験空間を構成する壁紙と照明の組み合わせは実験計画法 により採用された6通り［表1］を設定した。

表 1 実験空間の構成

\begin{tabular}{|c||c|c|}
\hline 空間 & 壁紙 & 照明 \\
\hline $\begin{array}{c}\mathrm{X} 1 \\
\text { [図5 上段左] }\end{array}$ & $\mathrm{W} 1$ & $\mathrm{~L} 1$ \\
\hline $\begin{array}{c}\mathrm{X} 2 \\
\text { [図5 下段左] }\end{array}$ & $\mathrm{W} 1$ & $\mathrm{~L} 3$ \\
\hline $\begin{array}{c}\mathrm{X} 3 \\
\text { [図5 上段中 }]\end{array}$ & $\mathrm{W} 2$ & $\mathrm{~L} 2$ \\
\hline $\begin{array}{c}\mathrm{X} 4 \\
\text { [図5 下段中 }]\end{array}$ & $\mathrm{W} 2$ & $\mathrm{~L} 3$ \\
\hline $\begin{array}{c}\mathrm{X} 5 \\
\text { [図5 上段右 }]\end{array}$ & $\mathrm{W} 3$ & $\mathrm{~L} 1$ \\
\hline $\begin{array}{c}\mathrm{X} 6 \\
\text { [図5 下段右 }]\end{array}$ & $\mathrm{W} 3$ & $\mathrm{~L} 2$ \\
\hline
\end{tabular}

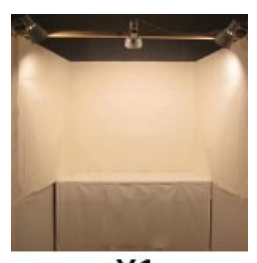

$\mathrm{X} 1$

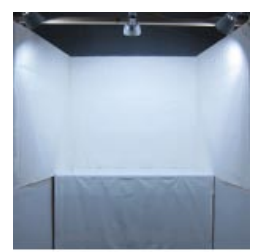

$\mathrm{X} 2$

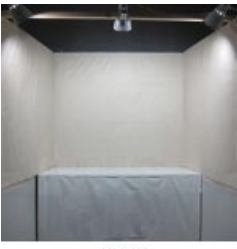

X3

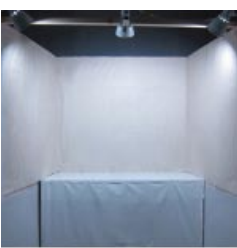

X4

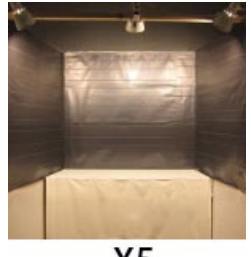

X5

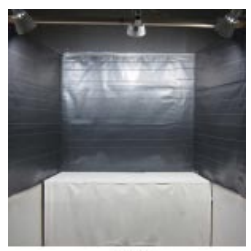

X6
図5 実験空間

\subsection{4 チョコレート}

刺激に用いたチョコレートは図6の6種類. すべて同一販 売店にて同価格（1点258円）で販売されていたものを用い た，実験中は高温による形状劣化を避けるため, テーブル上 に保冷剤を置き，その上に敷いた白色アクリル板の上に小皿 に乗せた状態で呈示した［図7］。

\section{5 評価項目}

チョコレート評価タスクでは呈示したチョコレートに対し て感じる「購入意欲」と「高級感」の評価を求め, 空間評価 タスクでは呈示した空間の壁紙と照明の組み合わせがどのく らい「高級感」を演出していると感じるかの評価を求めた. いずれも，評価は以下の5段階で回答させた。

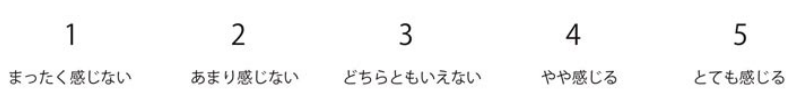

なお，実験参加者が評価対象を見ながら評価できるよう回 答は口頭で求め, 実験実施者が記録を行った。これは実験参
加者間で回答に要する時間を統制し, 明順応や色順応により 知覚の差異が生じないようにする目的もある.
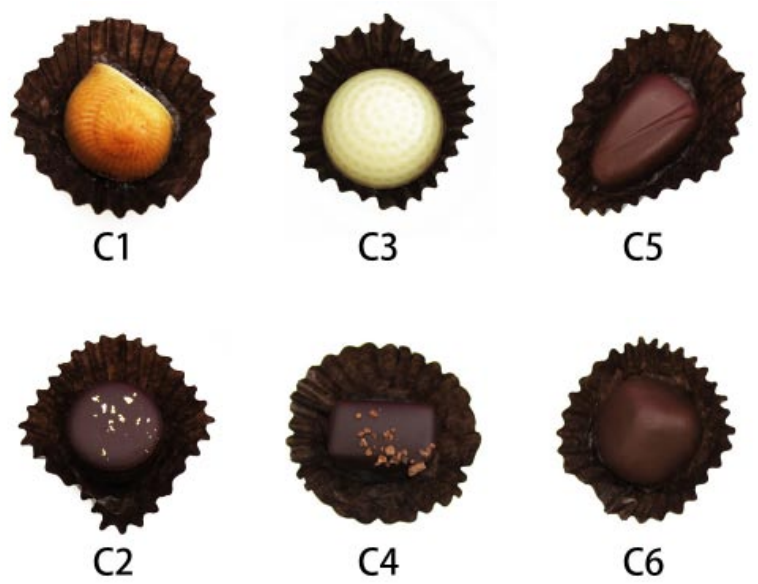

図6 チョコレート
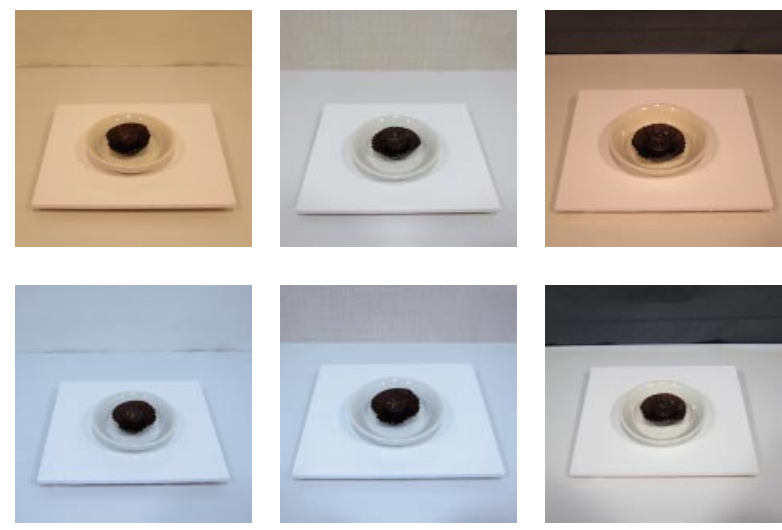

図7 チョコレートを呈示した例

\section{6 手続き}

実験を開始する前に実験参加者には実験内容の説明を行っ た、ただし，本実験の主目的が空間の評価であることを実験 参加者が知ってしまうと, チョコレートの評価をする際にも 空間を意識してしまい適切な結果が得られないと考えられ る。そこで, 実験参加者には本実験をチョコレートの評価実 験であると伝え，目的の詳細については実験終了後に説明を 行うことに同意を得た上で実験を開始した。実験は先にチョ コレート評価タスク 6 試行, 続いて空間評価タスク 6 試行を 行った。実験終了後には実験参加者に本実験の目的を説明 し, 了承を得た。

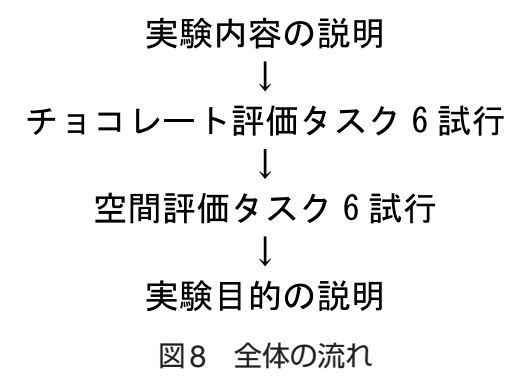

実験内容の説明 価タスク 6 試行 タスク 6 試行

的の説明

図8 全体の流れ 
実験参加者には実験室へ入室する際, 暗所を通過させるこ とで直前の視覚環境を統制した上で実験空間へ案内した。明 順応には30秒から 60 秒程度を要する [9] ため, 空間を呈示 してから 30 秒間は評価対象（チョコレート評価タスクでは チョコレート, 空間評価タスクでは壁紙と照明）を観察する よう指示し，その後，簡単に説明を行ってから評価を開始す ることで明順応に必要な時間を設けた。

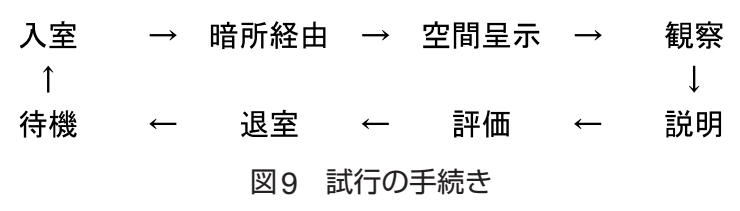

先の試行の影響を軽減するため, 1 試行が終了するごとに 実験参加者をいったん実験室から退室させて次の試行開始ま で別室で待機させ，その間に実験空間の壁紙と照明の交換作 業を行った。

チョコレートの評価は種類の違いによるばらつきや，空間 と交互作用が発生する可能性が否定できないため, チョコ レートの呈示順と空間との組み合わせを実験参加者ごとに入 れ替えることでカウンターバランスをとった.

\section{7 実験参加者}

実験参加者は20歳代の日本人学生, 男性 13 名, 女性 7 名 の計 20 名. 平均年齢は 22.7 歳であった.

\section{3. 結果と考察}

\section{1 実験の結果}

チョコレート評価タスクの結果と空間評価タスクの結果の 大まかな傾向を示すため, 空間ごと, 壁紙ごと, 照明ごとに 分けて評価值平均と標準偏差を算出し, 表2, 表3, 表4に 結果を示した。 なお, 高級感についてはチョコレート評価夕 スクで取得したものか, 空間評価タスクで取得したものかを 区別するため, 以降, 前者を「高級感 $(\mathrm{C})\rfloor$, 後者を「高級 感 $(X) 」$ と表記する.

\section{2 チョコレートと空間の評価値の相関}

はじめに, チョコレートの評価と空間の高級感評価の間 に相関があるかを調べたところ, 高級感 $(\mathrm{C})$ と高級感 $(\mathrm{X})$ については $\mathrm{r}=.216, \mathrm{p}<0.05 て ゙$, 購入意欲と高級感 $(\mathrm{X})$ に ついては $\mathrm{r}=.159, \mathrm{p}>0.05$ となり, 特に目立った相関は見ら れなかった。つまり, 高級感があると評価された空間で呈 示することによってチョコレートの高級感を演出できると いった単純な効果は, この結果を見る限り期待できないと 言える.

\section{3 評価値平均の差の分析}

評価值平均の差が有意なものであるかを確認するため, 空 間を構成する壁紙, 照明を要因として2要因の分散分析を
行った. 結果は表5にまとめた.

表2 空間ごとの評価值平均・標準偏差一覧

\begin{tabular}{|c|c|c|c|c|c|c|c|}
\cline { 3 - 8 } \multicolumn{2}{c|}{} & $\mathrm{X} 1$ & $\mathrm{X} 2$ & $\mathrm{X} 3$ & $\mathrm{X} 4$ & $\mathrm{X} 5$ & $\mathrm{X} 6$ \\
\hline \multirow{2}{*}{ 購入意欲 } & 評価値平均 & 3.25 & 2.55 & 2.95 & 3.30 & 2.70 & 2.90 \\
\cline { 2 - 8 } & 標準偏差 & 0.91 & 1.05 & 1.28 & 0.80 & 0.98 & 1.12 \\
\hline \multirow{2}{*}{ 高級感(C) } & 評価値平均 & 3.20 & 3.15 & 3.25 & 3.55 & 3.40 & 3.40 \\
\cline { 2 - 8 } & 標準偏差 & 1.01 & 0.99 & 1.07 & 0.89 & 1.14 & 1.00 \\
\hline \multirow{2}{*}{ 高級感 $(\mathrm{X})$} & 評価値平均 & 2.80 & 3.00 & 3.65 & 3.70 & 3.75 & 3.65 \\
\cline { 2 - 8 } & 標準偏差 & 0.83 & 0.92 & 0.99 & 0.80 & 0.72 & 0.75 \\
\hline
\end{tabular}

表3 壁紙ごとの評価値平均・標準偏差一覧

\begin{tabular}{|c|c|c|c|c|}
\cline { 3 - 5 } \multicolumn{2}{c|}{} & W1 & W2 & W3 \\
\hline \multirow{2}{*}{ 購入意欲 } & 評価値平均 & 2.90 & 3.13 & 2.80 \\
\cline { 2 - 5 } & 標準偏差 & 1.02 & 1.05 & 1.03 \\
\hline \multirow{2}{*}{ 高級感(C) } & 評価値平均 & 3.18 & 3.40 & 3.30 \\
\cline { 2 - 5 } & 標準偏差 & 0.97 & 0.97 & 1.04 \\
\hline \multirow{2}{*}{ 高級感 $(X)$} & 評価値平均 & 2.90 & 3.68 & 3.70 \\
\cline { 2 - 5 } & 標準偏差 & 0.86 & 0.88 & 0.71 \\
\hline
\end{tabular}

表4 照明ごとの評価値平均・標準偏差一覧

\begin{tabular}{|c|c|c|c|c|}
\cline { 3 - 5 } \multicolumn{2}{c|}{} & L1 & L2 & L3 \\
\hline \multirow{2}{*}{ 購入意欲欲価值平均 } & 2.98 & 2.93 & 2.93 \\
\cline { 2 - 5 } & 標準偏差 & 0.96 & 1.17 & 0.98 \\
\hline \multirow{2}{*}{ 高級感(C) } & 評価値平均 & 3.30 & 3.33 & 3.35 \\
\cline { 2 - 5 } & 標準偏差 & 1.05 & 1.01 & 0.94 \\
\hline \multirow{2}{*}{ 高級感 $(\mathrm{X})$} & 評価値平均 & 3.28 & 3.65 & 3.35 \\
\cline { 2 - 5 } & 標準偏差 & 0.89 & 0.85 & 0.91 \\
\hline
\end{tabular}

\section{表5 2要因分散分析の結果}

\begin{tabular}{|c|c|c|c|}
\hline & 購入意欲 & 高級感(C) & 高級感(X) \\
\hline 壁紙 & $F(2,114)=1.622 \quad p=0.156$ & $F(2,114)=0.877 \quad p=0.419$ & $F(2,114)=9.734 \quad p<0.000$ \\
\hline 照明 & $F(2,114)=0.616 \quad p=0.542$ & $F(2,114)=0.249 \quad p=0.780$ & $F(2,114)=0.225 \quad p=0.799$ \\
\hline 交互作用 & $F(1.114)=4.873 \quad p=0.029$ & $F(1,114)=0.394 \quad p=0.531$ & $F(1,114)=0.296 \quad p=0.587$ \\
\hline
\end{tabular}

反転セルは $5 \%$ 水準で有意な箇所を表す.

高級感 $(X)$ については壁紙に有意な主効果があり, 空間 の高級感の評価は壁紙によって差が生じたとわかる，購入意 欲については壁紙, 照明の主効果は有意でなかったが, 有意 な交互作用がみられた。これは，チョコレートに対する購入 意欲を評価させたにも関わらず，チョコレートの価值とは関 係のない周辺空間の壁紙と照明の組み合わせの違いによっ て, その評価に差異が生じた可能性を示唆している。また, 高級感（C）については有意な主効果や交互作用はなく, 周 辺空間の違いよる差は生じなかったようである。

以上の結果を受けて, まずは高級感 $(\mathrm{X})$ に対して, 壁紙 のどの水準間に有意差があったのかを確認するため, 多重比 較（Tukey HSD法）を行い, 結果を表6にまとめた。表の 通り, W1 とW2 およびW1 と W3 の間に $5 \%$ 水準で有意な差 が認められ, かつ評価值平均はW $1<\mathrm{W} 2$ かつ $\mathrm{W} 1<\mathrm{W} 3$ で あったため, 表2においてX1，X2が他の空間よりも高級感 （X）の評価值平均が低くなったことは，これらが壁紙W1 で構成された空間であることに起因していると考えられる。 
次に，購入意欲に対して，どの組み合わせ間の変動が大き かったために交互作用が有意となったのか, 単純主効果の検 定 (Bonferroni法)を行い確認した。結果は表7にまとめた通 りで，5\%水準で有意な差が認められたのは，壁紙がW1で, 照明がL1の場合と L3 の場合 $(\mathrm{L} 1>\mathrm{L} 3)$, 照明がL3で, 壁 紙がW1の場合とW2の場合 $(\mathrm{W} 1<\mathrm{W} 2)$ の 2 箇所であった。 これは空間に置き換えて考えると，X1 $>\mathrm{X} 2$ かつX $2<\mathrm{X} 4$ で あり，X2の空間が特にチョコレートに対する購入意欲を低 く評価させる効果があった可能性を示唆している.

表6＼cjkstart高級感（X) における壁紙の主効果の多重比較の結果

\begin{tabular}{|c|c|c|c|c|}
\cline { 4 - 5 } \multicolumn{2}{c|}{} & W1 & W2 & W3 \\
\hline \multirow{2}{*}{ W1 } & 差 & & -0.78 & -0.80 \\
\cline { 2 - 5 } & $\mathrm{p}$ & & 0.000 & 0.000 \\
\hline \multirow{2}{*}{ W2 } & 差 & 0.78 & & -0.02 \\
\cline { 2 - 5 } & $\mathrm{p}$ & 0.000 & & 1.000 \\
\hline \multirow{2}{*}{ W3 } & 差 & 0.80 & 0.02 & \\
\cline { 2 - 4 } & $\mathrm{p}$ & 0.000 & 1.000 & \\
\hline
\end{tabular}

「差」は平均値の差,「p」は有意確率，反転セルは $5 \%$ 水準で差が有意な箅所を表す

\section{表7 購入意欲における交互作用の単純主効果の検定の結果}
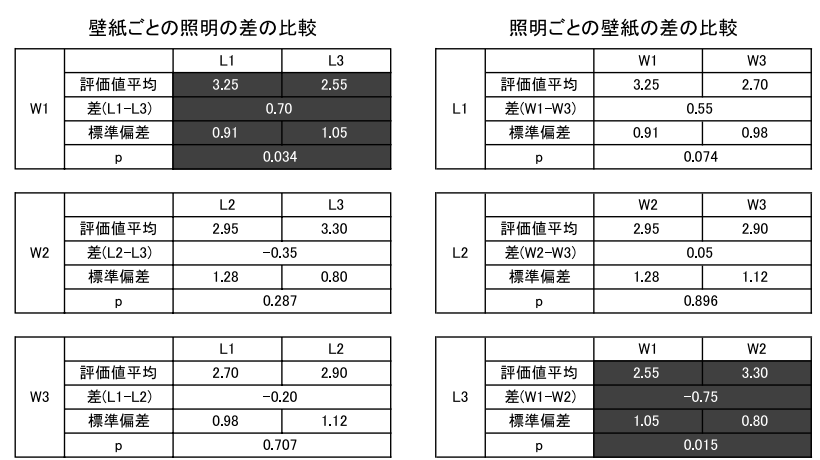

「差」は平均值の差,「p」は有意確率，反転セルは $5 \%$ 水準で差が有意な箇所を表す，

\section{4. 結 論}

本研究において実施した実験の結果から明らかになったこ とは，チョコレートの購入意欲評価という行為の結果に，空 間の視覚環境の違いが影響を与える可能性があるということ である、特に,壁紙W1 と照明L1から構成された空間 X1は, その空間の高級感がX2を除く他のすべての空間と比較して 有意に低いと評価されたが，一方で，X2 よりも空間内のチョ コレートに対する購入意欲評価では有意に評価が高くなると いう結果が見られた。

対して, チョコレートの高級感評価については空間の違い による有意な差は見られなかった。これは同じものを対象と した評価であっても, 主観が強くはたらく購入意欲の評価 と, 相対的な判断を含む高級感の評価とでは, その性質に違 いがあるからではないかと考えられる。この点はこれからさ らに詳しく確認が必要な課題である.

また，今回の実験では空間の高級感評価と, 空間内に呈示 したチョコレートの高級感評価との間には相関は見られず,
その関連性は不明であった。このことは空間に対する直接評 価から，空間が人に与える効果を推定することが困難である ことを確認する結果となった。

これらのことを踏まえると，本研究で提案した空間の間接 的な評価方法は，人が意識できず直接的な評価方法では取得 できないような空間の効果を推定するために有用なもので あったと考えることができる．同じ対象物についての評価で あっても，その評価内容によっては，空間の効果が確認でき ない可能性もあり, 直ちに応用が可能な汎用的な方法ではな いが，空間内の対象物を評価させた結果から周辺空間の効果 を間接的に取得するという新たな空間評価方法を提案し, 実 践することでその有用性を確認したという意味では，本研究 は十分に意義があったと言える。

今後は評価の対象物をチョコレートではなく他の商品で 行った場合にも空間の違いで評価結果を変化させることは可 能か，壁紙や照明以外の空間構成要素でも同様に結果を取得 することができるかといった点を確認していくことで，より 有用性のある手法が構築できると考える。

\section{参 考 文 献}

［1］槇究ほか：室内䨌囲気評価に及ぼす色彩・照明・素材の複 合効果, 日本建築学会計画系論文集 (516), pp.15-22, 1999-02-28.

２］中村肇ほか：照度・色温度が空間雲囲気に及ぼす影響, 照明学会全国大会講演論文集 29, pp.265，1996-08-31.

[3］魯斌ほか：居住環境における好ましい視覚環境に関する研 究, 日本建築学会研究報告 九州支部 2, 環境系 (46), pp.9-12, 2007-03-01.

[4] 勝浦哲夫：光の質で人間の生理反応は影響されるのか, 照明学会誌84 (6), pp.350-353, 2000-06-01.

５５］永留芙美ほか：異なる壁面色が及ぼす感覚時間の変化, 日本建築学会研究報告 九州支部 2, 環境系 (49), pp.125-128, 2010-03-01.

６］山田歩：情動 - 認知の誤帰属と処理の順序性, 対人社会心 理学研究 1, pp.171-184, 2001.

[7］下條信輔：行為の能動性はどこへ行くのか？：意思決定の 神経メカニズムをめぐって, 日本機械学會誌 109 (1049), pp.261-264, 2006-04-05.

［8］横井聖宏ほか：視覚的特徵により壁紙を分類する際のユー ザーの着目点の検討, 第 6 回日本感性工学会春季大会予稿 集, CD-ROM, 2011.

[9］島倉曈ほか：色順応刺激消失後における色の見えの時間推 移, 日本視覚学会学会誌 VISION 21 (2), pp.101-114, 2009. 


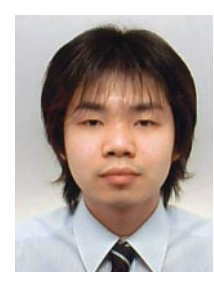

横井 聖宏 (学生会員)

2007 年, 筑波大学図書館情報専門学群卒業. 2009 年, 筑波大学大学院人間総合科学研究 科一貫制博士課程感性認知脳科学専攻にて修 士 (感性科学) 学位を取得. 現在も在籍. 知 覚・認知経験がヒトの意志決定に与える潜在 的な影響についての研究を行なっている.

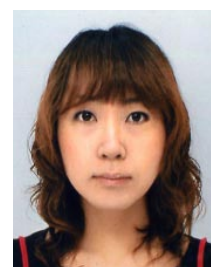

中島 瑞季 (学生会員)

多摩美術大学大学院美術研究科博士前期課 程・デザイン専攻修了。 2009 年, 筑波大学 大学院人間総合科学研究科一貫制博士課程感 性認知脳科学専攻にて修士 (感性科学) 学位 を取得. 現在も在籍. 研究主題は家庭用照明

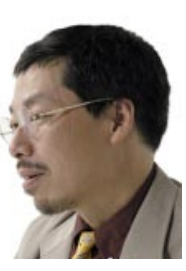

山中 敏正 (正会員)

1982 年千葉大学大学院工学研究科修士課程 工業意匠学専攻修了。旭光学工業デザイン室 デザイナー及び研究員, イリノイ工科大学特 別研究員, デルフト工科大学特別研究員を経 て，2005 年加筑波大学大学院人間総合科 学研究科教授. 日本デザイン学会理事. 国際デザイン学会連合 理事, 日本感性工学会副会長. 日本認知科学会, 日本人間工学 会会員. 博士 (感性科学).

器具のテザイン。 